
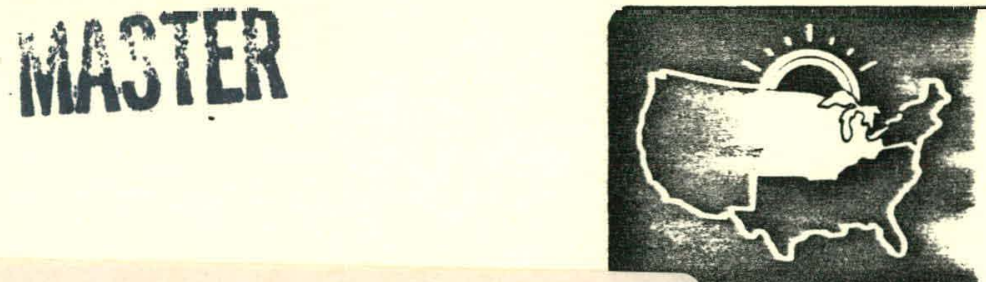

MASEC

MID-AMERICAN

SOLAR ENERGY

COMPLEX

MASEC-R--81-087

DE82 013418

\title{
Air Quality in Tightly Sealed and Passive Homes
}

Topical Report

September 1981

Prepared for

U.S. Department of Energy Under Contract No. DE-AC02-79CS30150

Submitted by Mid-American Solar Energy Complex 8140 26th Avenue South

Minneapolis, Minnesota 55420 


\section{DISCLAIMER}

This report was prepared as an account of work sponsored by an agency of the United States Government. Neither the United States Government nor any agency Thereof, nor any of their employees, makes any warranty, express or implied, or assumes any legal liability or responsibility for the accuracy, completeness, or usefulness of any information, apparatus, product, or process disclosed, or represents that its use would not infringe privately owned rights. Reference herein to any specific commercial product, process, or service by trade name, trademark, manufacturer, or otherwise does not necessarily constitute or imply its endorsement, recommendation, or favoring by the United States Government or any agency thereof. The views and opinions of authors expressed herein do not necessarily state or reflect those of the United States Government or any agency thereof. 


\section{DISCLAIMER}

Portions of this document may be illegible in electronic image products. Images are produced from the best available original document. 
This material was prepared under sponsorship of the Mid-American Solar Energy Complex (MASEC) and the U. S. Department of Energy. Neither MASEC, the United States or any agency thereof, nor any of their employees, makes any warranty, expressed or implied, or assumes any legal liability or responsibility for any third party's use or the results of such use of any designs, information, apparatus, product, or process disclosed in this material, or represents that its use by such third party would not infringe on privately owned rights. 

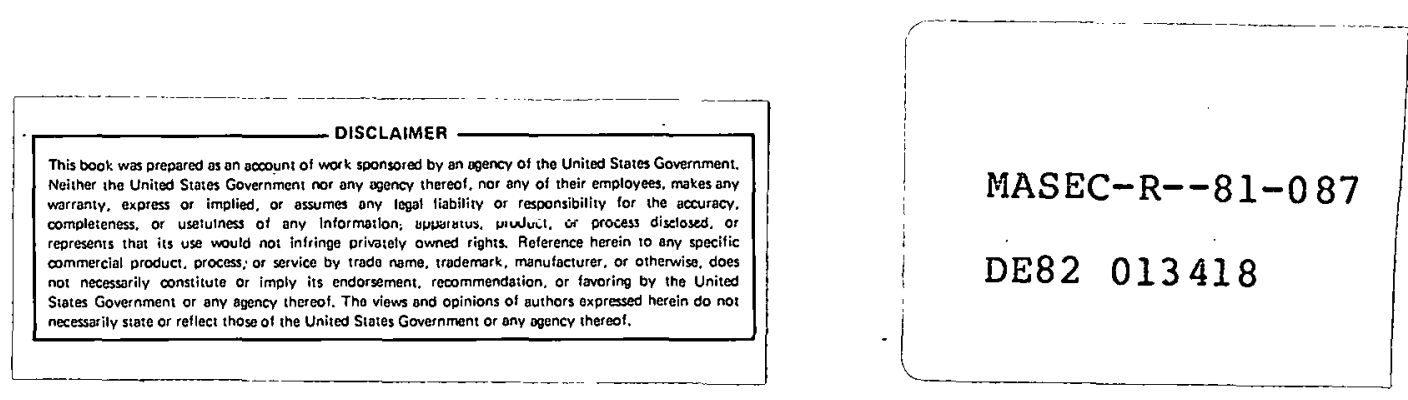

Air Qualicy

In Tightly Sealed and Passive Homes

Topical Report

September 1981

By

Linda A. Scott, PhD.
Mid-American Solar Energy Complex
814026 th Avenue South
Minneapolis, Minnesota 55420

\author{
Prepared for the \\ U.S. Department of Energy \\ Division of Conservation and Renewable Energy \\ Under Contract DE-ACO2-79CS30150
}

P-101-17

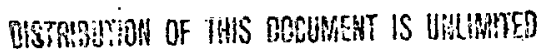


CONTENTS

Section

Page

INTRODUCTION................................

INDOOR AIR POLLUTANTS $\ldots \ldots \ldots \ldots \ldots \ldots \ldots \ldots \ldots \ldots \ldots \ldots \ldots \ldots \ldots$

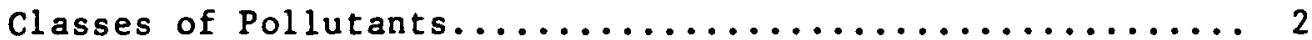

Impact of Passive Solar on Indoor Air Quality.......... 2

Health Effects of Elevated Indoor-Generated Pollutants.... 3

Control Strategies......................... 5

AIR-TO-AIR HEAT EXCHANGERS FOR RESIDENCES............. 7

General Requirements...................... 7

Design of Air-to-Air Heat Exchangers.............. 8

General Performance of Air-to-Air Heat Exchangers........11

Air Quality in a Tightly Built House...............11

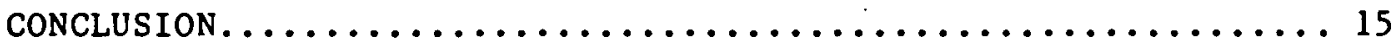

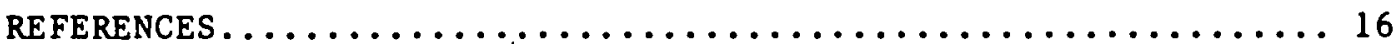




\section{TABLES AND FIGURES}

Page

- TABLE 1, Indoor Pollutant Characteristics, Impacts and Controls.............................. 6

TABLE 2, Heat Loss Percentages from a Typical House......... 7

TABLE 3, Contaminant Concentrations in a Test Ritchen....... 13

TABLE 4, Indoor/Outdoor Formaldehyde and Aliphatic Aldehyde Concentrations at an Energy-Efficient Residence......... 13

FIGURE 1, Residential Air-to-Air Heat Exchanger............ 


\begin{abstract}
Indoor air quality has attracted increasing attention during the past few years. Pollutants generated from combustion, building materials and human activities may reach significant levels in the indoor environment to produce adverse health effects. This report deals with the classes of pollutants and their sources, and the significance of reported levels, possible health effects, and control strategies in relation to tightly sealed and passive solar construction techniques. In tightly sealed homes, residential air-to-air heat exchangers offer one method of improving air quality at reasonable cost. It is recommended that further research be implemented to identify hazardous concentrations of pollutants and set standards to minimize health impacts in the search for new energy innovations.
\end{abstract}




\section{INTRODUCTION}

Energy consumption patterns are being reexamined because of the growing concern over the availability and price of conventional energy sources. Proposed solutions to the energy problem range from new forms of energy production to energy conservation. However, each new energy system introduced into the indoor residential environment has the potential to alter indoor air quality.

Unfortunately, no guidelines exist for indoor air quality standards similar to the ones established for ambient air quality. Also, application of ambient air quality standards for indoor air is not applicable because of the large amount of time spent indoors ( 70 percent) and the variability of pollutants which can emanate from indoor sources.

Comprehensive studies. in Europe and the United States are developing recommendations for indoor air quality standards. Through the use of scientific measurements and analysis methods, those energy innovations compatible with the maintenance of a healthy indoor environment are being identified. 
INDOOR AIR POLLUTANTS

Classes of Pollutants

There are three major source classes of indoor air pollution: 1) outdoor generated pollutants entering the indoor environment through infiltration; 2) indoor-generated pollutants, the primary sources being combustion $\left(\mathrm{CO}_{2}, \mathrm{NO}_{2}\right.$, particulates); and, 3$)$ indoor-generated pollutants with the primary source being human activities $\left(\mathrm{CO}_{2}\right.$, hydrocarbons, particulates) and building contents or materials (formaldehyde, radon, asbestos).

Impact of Passive Solar on Indoor Air Quality Conditions influencing indoor air quality for passive energy systems would be: 1) reduced infiltration and ventilation (about 0.75 air changes per hour [ACH] or less); 2) different quantities and ratios of building material (thermal mass, concrete, cement blocks, tile floors, bricks, etc.); 3) addition of sunspace or greenhouse to living space; 5 ) increased sunlight in living space; 5) increased use of wood combustion systems; and, 6) increased exposure of living space to soil (e.g., berming).

Reduced ambient infiltration actually shields indoor spaces from outdoor generated pollutants.

The other two classes of indoor-generated pollutants, however, could impose health risks to the occupants. Major combustion pollutants ( $\mathrm{CO}, \mathrm{NO}, \mathrm{NO}_{2}$, particulates, and hydrocarbons, particularly aldehydes) because of additional wood cumbustion, or fossil fuel (especially gas) combustion for heating or cooking operations as well as tobacco smoke with reduced ventilation could increase to a significant level. Indoor pollutants from building materials would also be increased due to extensive use of radonemitting materials for thermal mass e.g., concrete, bricks, tile. Further, with the addition of greenhouse space, more pollutants may be released into the living space environment, e.g., hydrocarbons from insecticides and cleaning supplies, radon from soil.

Also, with additional sunlight, increased pollutant levels or humidity could influence photochemical oxidation and conversion of indoor air pollutants to other health-risk products. 
All of these pollutants may rise to significant levels due to energy conservation in the form of reduced infiltration.

Actual measurement data on indoor air pollutant concentrations in buildings with alternative energy systems is minimal. Hollowell, et al, 1 have measured pollutants from gas stove emissions in buildings with reduced ventilation $(0.2-0.3 \mathrm{ACH})$. These investigations indicated significant levels of $\mathrm{CO}$; $\mathrm{NO} / \mathrm{NO}_{2}$, respirable aerosols, particulate sulfur, nitrogen and carbon compounds with infiltration of less than one air change per hour. In a public building with no indoor-generated combustion sources, the research team reported no significant increase in indoor pollution levels with reduced ventilation rate. The exception was $\mathrm{CO}_{2}$ from human metabolic activity, which was still far below levels considered a health hazard. In fact, the air quality improved for outdoor generated sources of $\mathrm{NO}_{2}$ and $\mathrm{O}_{3}{ }^{2}$.

Pollutants emanating from building materials in relationship to reduced ventilation were also investigated by this group. The results indicated increased radon and radon daughter levels $\mathrm{s}^{2,3}$ and formaldehyde levels $\mathrm{s}^{2}$ with reduced ventilation. Studies on levels of hydrocarbons or other pollutants or studies on generation of secondary pollutants through decay or photochemical oxidation have not been conducted. Little literature exists on the impact of alternative energy systems components on the indoor environment. One investigation has cited the ambient environmental impact of alternative energy sources ${ }^{4}$. Another investigator presented data where infiltration effects overwhelmed radon emission levels from granite rock storage ${ }^{5}$.

Heal th Effects of Elevated Indoor-Generated Pollutants

Pollutants generated from the combustion of fossil fuels, wood, or tobacco have implications for adverse health risks. Elevated nitrogen dioxide levels have been correlated with acute and chronic respiratory diseases as well as possible increased mortality from cardiovascular diseases and cancer. The possible conversion products formed from catalytic oxidation (nitrates, nitric arid, ammonium, nitrosamine, and organic nitrogen 
compounds of amino and pyridino type) are implicated in respiratory disease and are suspected carcinogens. The health effects of carbon monoxide from fossil fuels, gas, wood, and tobacco combustion are well known: 1) acutely elevated levels cause nausea, vomiting, asphyxiation, coma, and death; and 2) low levels cause headache and dizziness.

Particulate matter in various forms from fossil fuel, wood, and tobacco combustion are a complicated class of pollutants. They cause adverse health effects alone or through interaction with other pollutants e.g., the interaction of $\mathrm{SO}_{2}$ and elevated particulate levels has been well documented. The wide spectrum of adverse health effects from this variant group range from respiratory disease to cardiovascular disease and cancer.

The major pollutants emitted from building materials also are a potential health risk. The adverse health effects of radon from concrete blocks, soil, groundwater, particleboard, etc. are increased risk of lung and other cancers. Health effects of chronic exposure to asbestos released from insulation range from asbestosis to bronchogenic carcinoma to neoplasms. Acute asbestos exposure can cause plural or peritoneal mesothelioma 15 or more years after exposure. Formaldehyde emanating from wallboard or insulation, and tobacco smoke in low levels cause eye, nose, and upper respiratory tract irritation while acute high level exposure causes deeper respiratory irritation. Other chronic exposure-related health risks are not known. Other major sources of indoor generated pollutants may also pose potential health risks. Exposure to excessive hydrocarbon levels from cooking, pesticides in greenhouses, cleaning supplies, spray can propellants, wood combustion etc., can, in general, depress the central nervous system. The extensive variety of these hydrocarbons causes a varied spectrum of health effects including impacts on the respiratory, cardiovascular, and clearance systems. Elevated chronic carbon dioxide exposure from human metabolism could change the acid base balance of the human system upon which all metabolic activity is based.

The health effect of conversion products from photochemical oxidation, increased pollutant levels or humidity are varied. The health effects range from irritation to involvement of the respiratory and cardiovascular systems and cancer. 
Control Strategies

The control of gaseous combustion generated pollutants can be accomplished several ways: 1) source removal (e.g., using electric cooking appliances, prohibiting tobacco smoking, eliminating wood combustion); 2) source ventilation (e.g., appliance ventilation, adequate fireplace and woodstove ventilation systems); 3) air-to-air heat exchangers to provide ventilation but minimize heat loss; and 4) absorption by activated carbon filter systems. These control strategies are summarized here. A detailed description of air-to-air heat exchangers is contained in a separate section later in this report.

Control methods employed to control combustion generated gaseous pollutants are also applicable for combustion-generated particulate pollutants. However, air-to-air heat exchangers are only partially effective. Absorption by activated carbon is not applicable to particulate pollutants. Effective controls include the employment of inert filter devices and electrostatic precipitators which remove particulates.

The control of pollutants emanating from building materials includes:

1) material substitution (i.e., prohibit the use of building materials with excessive emissions of formaldehyde, asbestos, or radon); 2) sealants and barriers (i.e., seal the asbestos from releasing fibers, use polyethylene sheets or epoxy paints to seal materials from radon outgassing); 3) air-toair heat exchangers (i.e., reduce formaldehyde and radon by ventilation with minimal heat loss); 4) absorption by activated carbon (e.g., radon and formaldehyde) or absorptive environmental surfaces (e.g., formaldehyde by special surfaces); 5) electrostatic precipitators with high voltage remove radon and radon daughters.

The control of human activity related pollutants (hydrocarbons or $\mathrm{CO}_{2}$ ) would be obtained by 1 ) source removal (e.g., prudent use of cleaners, pesticides, spray can propellants; reduction of tobacco smoking); 2) sparse ventilation requiring use of the product only in adequately ventilated areas; 3 ) maintenance of general ventilation with minimal heat loss by use of air-to-air heat exchangers (e.g., $\mathrm{CO}_{2}$ and general hydrocarbon removal); and 4) absorption by activated carbon (e.g., hydrocarbon emission).

MASEC has on file a comprehensive bibliography on air pollutants and air-toair heat exchangers that includes nearly 800 entries. Table 1 is a summary of indoor pollutant characteristics, impacts and controls. 
TABLE I

INDOOR POLLUTANT CHARACTERISTICS, IMPACTS, AND CONTROLS

\begin{tabular}{|c|c|c|c|c|c|}
\hline POLLUTANT & MAJOR SOURCES & FORM & EXPOSURE LEVELS INDOORS & HEALTH IMPACTS & EXAMPLE CONTROL STRATEGIES \\
\hline Sulfur Dioxide & $\begin{array}{l}\text { Aabient Air } \\
\text { Indour: fossil fuel } \\
\text { combustion }\end{array}$ & Gas & $\begin{array}{l}\text { Ambient source: significantly } \\
\text { lower than outdours }\end{array}$ & $\begin{array}{l}\text { Risk of acute and long-term } \\
\text { respiratury effects in cun- } \\
\text { junct ion with particulates/ } \\
\text { cunversion producte--respira- } \\
\text { tury effects, heart disease, } \\
\text { neoplasms }\end{array}$ & $\begin{array}{l}\text { Absurptive ourfaces, source } \\
\text { ventilation, ventilation }\end{array}$ \\
\hline Nitrugen Oxides & $\begin{array}{l}\text { Ambient air, vehicle } \\
\text { emiasion } \\
\text { Indour combustion: car- } \\
\text { bonaceoug fuels (gas } \\
\text { otoves and heating, wood } \\
\text { and tobacco combugtion }\end{array}$ & Gas & $\begin{array}{l}\text { Antient source: lower or } \\
\text { approx. same as andient } \\
\text { levels. Indoor source: } \\
\text { significant levels with } \\
\text { unvented conbustion }\end{array}$ & $\begin{array}{l}\text { Risk of acute reopitatory } \\
\text { effects, chronic respiratury } \\
\text { effects, possible increased } \\
\text { mortality from cardiuvascular } \\
\text { disease and cancer/Conversion } \\
\text { products: respiratory effects } \\
\text { and guspected carcinogens } \\
\end{array}$ & $\begin{array}{l}\text { Source removal, ource ventila- } \\
\text { tion. Absorption by ectivated } \\
\text { carbon, ventilation }\end{array}$ \\
\hline \multirow[t]{2}{*}{ Carbon Oxides } & $\begin{array}{l}\text { Ambient air, vehicle } \\
\text { emiasion } \\
\text { Indour combustion; car- } \\
\text { bonaceus fuels, (woud- } \\
\text { stoves, tobscco) infil- } \\
\text { tration frum garage }\end{array}$ & Gas & $\begin{array}{l}\text { Ambient source: approximates } \\
\text { patterns of outdoor levels. } \\
\text { Indoor gource: gignificant } \\
\text { levels vith unvented } \\
\text { combugtion. }\end{array}$ & $\begin{array}{l}\text { Lower concentrations: headoche } \\
\text { dizziness. } \\
\text { Higher concentrations: nausea } \\
\text { vomiting, asphyxiation, death }\end{array}$ & $\begin{array}{l}\text { Source removal, source ventila- } \\
\text { tion, ventitatiun, catalytic } \\
\text { oxidation, complete conbustion. }\end{array}$ \\
\hline & Retabolic activity & & $\begin{array}{l}\text { Tndoot Source: not significant } \\
\text { acute exposures. } \\
\text { Elevated chronic exposures: }\end{array}$ & $\begin{array}{l}\text { Chronic Tevero: change } \\
\text { acid base balance }\end{array}$ & Ventilation \\
\hline $\begin{array}{l}\text { Photuchemical } \\
\text { Oxidants }\end{array}$ & Ambient air & & $\begin{array}{l}\text { Ambient source: significantly } \\
\text { lower than outduors }\end{array}$ & $\begin{array}{l}\text { Eye irritation, respiratory } \\
\text { discomfort, chronic exposure } \\
\text { not understoud. }\end{array}$ & Absorptive surfaces, ventilation \\
\hline Particulates & $\begin{array}{l}\text { Ambient air } \\
\text { Indour cumbustion: (gas } \\
\text { stoves, wood and tobacco } \\
\text { combustiun, heating } \\
\text { Burces) resuspension } \\
\text { from physical activity } \\
\end{array}$ & $\begin{array}{l}\text { Parti- } \\
\text { culate }\end{array}$ & $\begin{array}{l}\text { Ambient sources: lower than } \\
\text { outduors. } \\
\text { Induor gource: oignificant } \\
\text { levels frum indoor combution. }\end{array}$ & $\begin{array}{l}\text { Varied: range from respiratury } \\
\text { to cardiovascular disease and } \\
\text { cancer }\end{array}$ & $\begin{array}{l}\text { Source removal, source ventila- } \\
\text { tion filters, electrostatic pre- } \\
\text { cipitators, ventilation }\end{array}$ \\
\hline Asbestus & $\begin{array}{l}\text { Insulatiun or decora- } \\
\text { tive sprays }\end{array}$ & $\begin{array}{l}\text { Parti- } \\
\text { culate } \\
\text { fiber }\end{array}$ & $\begin{array}{l}\text { Induor source: variable } \\
\text { aignificance of levels unknown }\end{array}$ & $\begin{array}{l}\text { Asbestuais to brunchorenic } \\
\text { carcinuma to neoplasms (compli- } \\
\text { cated by cigarete smukers) } \\
\text { Rigk of acute exposures: pleural } \\
\text { or perituneal mesothelioma } 15 \\
\text { years later. }\end{array}$ & $\begin{array}{l}\text { Source remuval, material substi- } \\
\text { tution or sealing. }\end{array}$ \\
\hline Hyd = ocerbons & $\begin{array}{l}\text { Ambient Air } \\
\text { Induor cumbustion: } \\
\text { carbonaceouus levels, } \\
\text { (cooking, woud and } \\
\text { tobaccu combustion) } \\
\text { pesticides, gpray pro- } \\
\text { pellants, cleaning } \\
\text { oul vents }\end{array}$ & Gas & $\begin{array}{l}\text { Ambient source: approximates } \\
\text { outdoor levels } \\
\text { Induor generation: actue ex- } \\
\text { posure can be extremely high, } \\
\text { chronic exposure al oo noted }\end{array}$ & $\begin{array}{l}\text { Risk of a variety of severe } \\
\text { acute and long term effects } \\
\text { including depression of central } \\
\text { nervous aystem }\end{array}$ & $\begin{array}{l}\text { Source removal, source ventila- } \\
\text { tion bourption by activated }\end{array}$ \\
\hline Furmal dehyde & $\begin{array}{l}\text { Building materials, } \\
\text { wallboard, insulation } \\
\text { cobacco smuke }\end{array}$ & Gas & $\begin{array}{l}\text { Indoor source: can be signif- } \\
\text { icant depending on building } \\
\text { materials }\end{array}$ & $\begin{array}{l}\text { Low levels: eye, nose and upper } \\
\text { respiratnry tract irritation } \\
\text { High levela: deeper respiratory } \\
\text { irritation }\end{array}$ & $\begin{array}{l}\text { Source renoval material } \\
\text { substitution, activated carbon } \\
\text { absurption, ventilation, abourp } \\
\text { tion by opecial surcaces, oxida- } \\
\text { tion. }\end{array}$ \\
\hline Radun & $\begin{array}{l}\text { Surrounding soil of fill } \\
\text { Auilding materials- } \\
\text { bricks, concrete, stone. }\end{array}$ & $\begin{array}{l}\text { Gas o } \\
\text { Parti- } \\
\text { culate }\end{array}$ & $\begin{array}{l}\text { Significantly higher than } \\
\text { than outduor levelo dependent } \\
\text { on ventilation levels }\end{array}$ & $\begin{array}{l}\text { Enhanced risk of lung and other } \\
\text { cancers }\end{array}$ & $\begin{array}{l}\text { Radun pas - activated carbon } \\
\text { absurption, ventilation } \\
\text { Ratun daughters - electrostatic } \\
\text { precipitators (ESP), fillers, } \\
\text { ventilation, radon gas barriers } \\
\text { (polyethylene sheets, epoxy } \\
\text { paints, etc.) }\end{array}$ \\
\hline
\end{tabular}




\section{AIR-TO-AIR HEAT EXCHANGERS FOR RESIDENCES}

\section{General Requirements}

A considerable amount of energy is required to heat the ventilation air in residences. Depending on the size and type of home construction, about one-quarter to as high as one-half of the heating energy consumed goes to heat the air. Even in a very well sealed house, air must be introduced to control excess humidity, to control odors, and to provide oxygen for the residents.

Typically in new construction, infiltration occurs at the rate of about one-half of an air exchange per hour. That is to say, that the volume of air inside the house is interchanged with outside air about once every two hours. The amount of heat required to warm the air during the heating season amounts to about 25 percent of the total heating load (Table 2). By proper sealing techniques it is possible to construct a home in such a manner to lower this amount of air exchange, but a practical limit of about one-quarter of an air exchange per hour is the minimum that one should allow.

TABLE 2

\section{Heat Loss Percentages from Typical House}

$$
\text { (1961-1975) }
$$

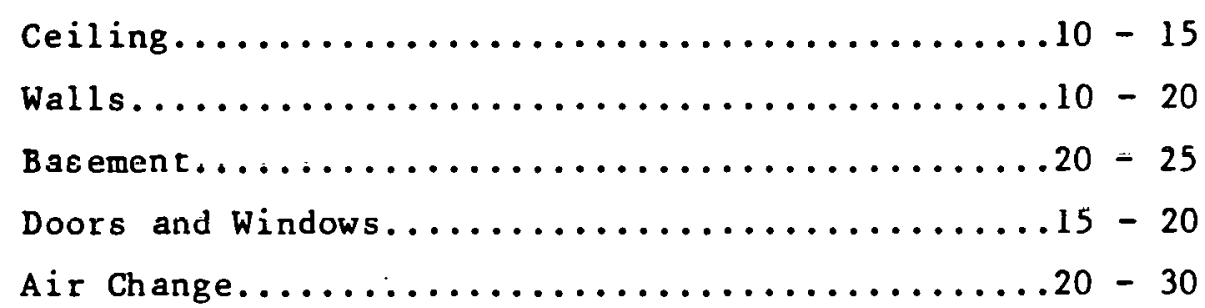

A way to reduce the heat loss associated with ventilation air is to use an air-to-air heat exchanger to transfer the heat from the outgoing stale warm air to the incoming cold air. An air-to-air heat exchanger will also reduce excessive amounts of water vapor in a dwelling. An air-to-air heat exchanger, however, will not be of any value in a poorly sealed home. The heat exchanger will be of value only if one can control the movement of air into and out of the house. If leaky doors, windows, clectrical outlets, 
fireplace dampers, kitchen fan exhaust, bathroom fan exhaust, gas, oil or wood furnace chimneys provide additional paths for the air to enter or leave the house, then the heat exchanger will be of little value. For new home construction one would want to include the following features to control air leakage.

1. Use vestibule entrances with two doors for all exits from the house.

2. Use sealed windows or, if openable, casement or awning-type windows. Avoid double hung or sliding windows.

3. Avoid sliding patio doors.

4. Insure a complete vapor barrier seal around the house.

5. Use a recirculating range hood for the kitchen, rather than an outside venting-type hood.

6. Vent the bathroom $f a n$, if used, into the air-to-air heat exchanger.

7. Vent the dryer vent, into the air-to-air heat exchanger (electric dryer only).

8. If using fuel burning furnaces (gas, oil, wood, coal) completely isolate the combustion air and the chimney air from the house air. One way to do this is to build a tight enclosure around the furnace, and supply the combustion air and chimney air directly from outside the house. Alternatively, special ducting to supply combustion air and chimney air to the furnace may be used. A number of furnace suppliers are now testing such units.

With an existing home built to conventional standards, considerable changes along the above lines may be required to effectively make use of the air-to-air heat exchanger.

\section{Design of Air-to-Air Heat Exchangers}

Figure 1 shows a simplified line drawing of a residential air-to-air heat exchanger. It is basically an insulated box with two internal blowers and two pairs of inlet/outlet ports. Port 1 is used to exhaust warm air from inside the residence. Outlet Port 2 provides a means of exhausting this air, which is vented to the outside of the residence. Port 4 is an intake port which brings cool fresh outside air and admits it to the inside of the structure. The quality of the air to be established inside the residence is dependent on the quality of air in this flow stream. Port 3 is an exhaust 


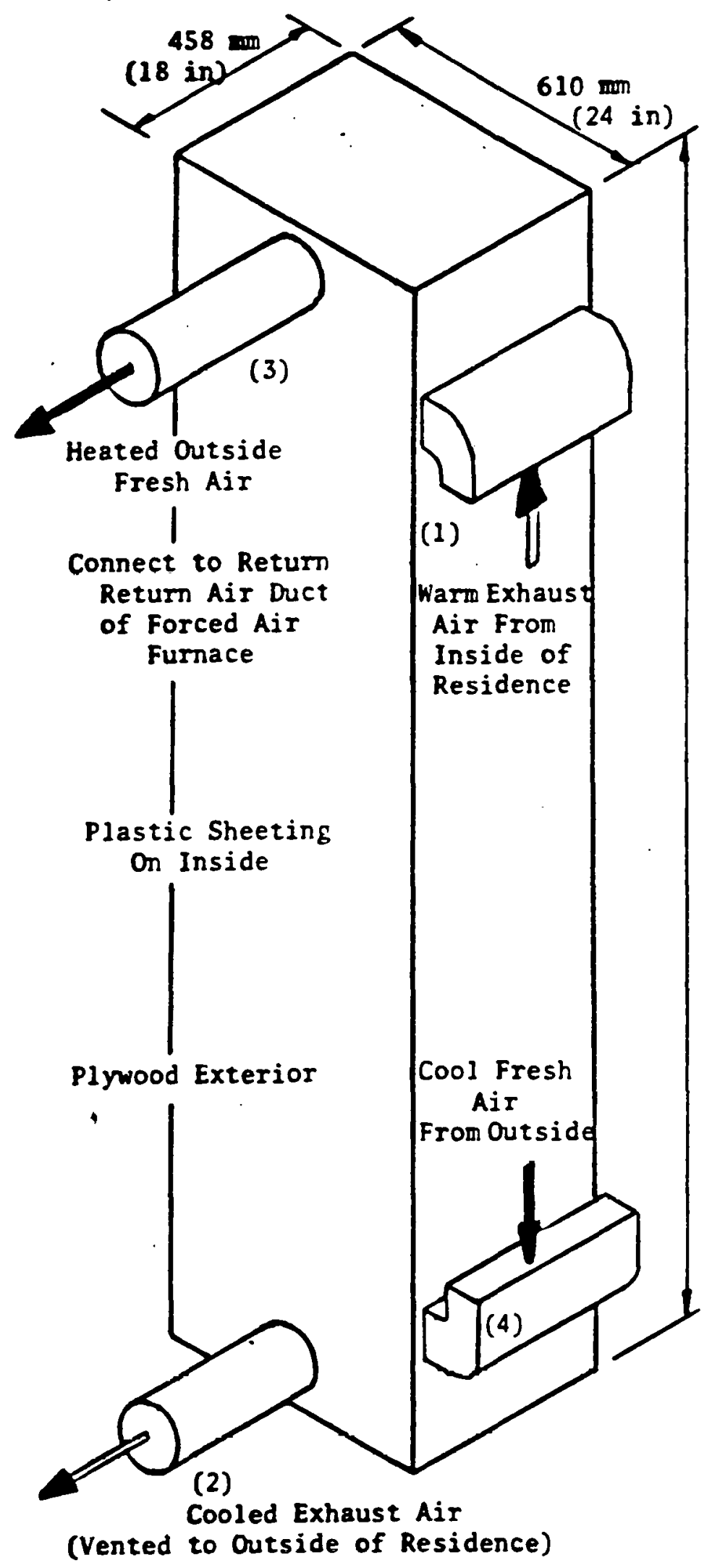

figure ? REsIdentIal aIR to aIR heAt EXCHANGER 
port which brings the now heated outside fresh air and admits it to the inside of the residence: This port is typically connected to the return air duct of a forced air furnace heating system, if one exists. Internal to the air-to-air heat exchanger are two relatively low flow rate air blowers. Air blower \#1 supplies the energy necessary to move warm exhaust air from inside the residence through Port 1 and exhaust this now cooled air to the outside

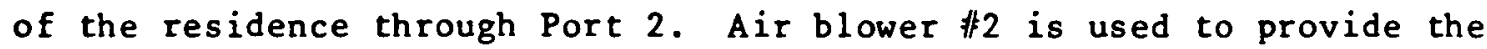
energy necessary to bring the cool fresh outside air past the internal heat exchange elements and exhaust this now heated outside fresh air to the return air duct of the forced air furnace heating system. Here this air can be mixed with the air returning to the furnace from the house. As an alternative, the fresh air from the heat exchanger may be vented directly into the living areas of the house.

As moist air from inside the house travels through the air-to-air heat exchanger, moisture can condense out of the air stream if the air stream is cooled below the dew point. Also, if the air stream leaving the house is further cooled inside the heat exchanger to below the freezing point of water, ice crystals will form inside the heat exchanger. A carefully designed heat exchanger, therefore, should provide means of removing this moisture and ice. A drain pan at the base of the exchanger will serve to collect this moisture. If the air-to-air heat exchanger is operated in the freezing condition mentioned, one must periodically defrost the device. The frequency of defrosting depends on several variables--the outdoor air temperature, the indoor air relative humidity, and the air flow rate through the heat exchanger. Some manufactured heat exchangers provide. automatic defrost action. In a mild climate, one would have to defrost the heat exchanger only a few times per winter. Under the worst conditions experienced such as in the Canadian Prairies, one would have to defrost about once per day.

Defrosting can be accomplished in a number of ways. One way is simply to turn off the fan. Depending on the outdoor air condition and the degree of frosting, the frost will fall to the drain pan in anywhere from a few hours to a few days. In the severe locations, heat exchangers with built-in electric resistance defrosters should be used to assure continuous heat exchanger operation. 
General Performance of Air-to-Air Heat Exchangers

The general performance of these heat exchangers is best represented by its thermal efficiency. The thermal efficiency or heat recovery ratio is a relative measure of the amount of heat that is actually recovered and returned to the residence as compared with the amount of heat that exits the residence through Port 1 of the heat exchanger. In an average residence with an interior volume of about 16,000 cubic feet, a flow rate of about one-half an air exchange per hour should be sufficient to keep the house air pleasant. This would amount to an air flow of about 140 cubic feet per minute continuously through the heat exchanger. In general, if excessive humidity in winter or high odor levels are present, the air flow should be increased. If low humidity or dryness are present and odors are not a problem, the air flow may be reduced. Under normal operating conditions (no frost build-up), the outside air introduced to the heat exchanger should be raised to within a few degrees Celsius of the temperature of the air inside the house. Consider the example of a residence exhausting air at $20^{\circ} \mathrm{C}$ to an outside ambient air temperature of $-35^{\circ} \mathrm{C}$. The $-35^{\circ} \mathrm{C}$ outside air, however, is warmed to about $15^{\circ} \mathrm{C}$ as it passes through the heat exchanger.

Air Quality in a Tightly Built House

The air infiltration rates in today's generation of energy efficient houses range from 0.2 to 0.5 air changes per hour $(\mathrm{ACH})$, compared with 0.8 to 1.0 $\mathrm{ACH}$ in conventional residential buildings. There has been concern that tightly constructed, heavily insulated homes are so well sealed that the quality of the indoor air poses a health hazard. The relationship of air quality and air-to-air heat exchangers is summarized below. A more general discussion of indoor air pollutants may be found in an earlier section of this report.

With respect to health effects, there are two potential sources of pollution: the outside, and the inside. Air quality in many major cities is not always safe. To assume that people require high air infiltration to flush out indoor air pollutants ignores this fact. Houses can give shelter from some outdoor sources of pollutants, so real benefits can stem from building houses with low air infiltration rates. Studies are presently being conducted on the subject of indoor air pollution. Good studies being 
conducted by Lawrence Berkeley Laboratories and others may give us the definitive data that we need to assess this problem.

Table 3 shows the indoor air pollutant levels in a test kitchen under four gas cooking procedures from no stove vent to a hood vent with fan at high speed. To reduce the levels of carbon monoxide ( $\mathrm{CO}$ ), nitrogen dioxide $\left(\mathrm{NO}_{2}\right)$, and formaldehyde ( $\mathrm{HCHO}$ ) to the most stringent health standard, a gas kitchen range must have a hood vent with a fan capable of approximately 140 cubic feet per minute.

HCHO is found in many products used by the building trades, including. particle board, plywood, and adhesives. HCHO is also produced in the combustion process of gas cooking and heating, and in tobacco smoke. In concentrations above 100 micrograms per cubic meter, HCHO irritates eyes and the upper respiratory tract. The HCHO measurements made by Lawrence Berkeley Laboratory at an energy efficient house in Mission Viejo, California are highlighted in Table 4. The indoor HCHO concentration did not meet health standards (Netherlands has established a maximum level of 120 micrograms per cubic meter) day or night during occupancy, or during the period of vacancy with furniture in the house. During the test, the outside air HCHO level was always less than 10 micrograms per cubic meter. During occupancy in the day, the air infiltration rate was about $0.4 \mathrm{AC} /$ hour. While the HCHO concentration rate was reduced at night when windows were open for ventilation, the HCHO concentration was still above 120 micrograms per cubic meter.

These findings agree with the study headed by Moschandress of Indoor Air Pollution in Energy Conserving Houses. The researchers evaluated indoor air pollution in 15 residential structures in five cities across the country. The air exchange rates in these houses range from 0.2 to 1.05 . Sophisticated equipment was used to measure indoor and outdoor air pollution levels in a 14 day period. Summarizing their findings:

- Concentrations of nitrogen dioxide, total suspended particulates, and respirable suspended particulates are sometimes higher than they were outdoors; 
TABLE 3

Contaminant concentrations in a test kilchen.

\begin{tabular}{|c|c|c|c|c|c|}
\hline \multirow[b]{2}{*}{ Ventllation Conditions } & \multirow[b]{2}{*}{$\begin{array}{l}\text { Mechanical } \\
\text { Ventilation } \\
\text { Rate }\left(\mathbf{m}^{3} / \mathrm{hr}\right)\end{array}$} & \multirow[b]{2}{*}{$\begin{array}{l}\text { Air Exchange } \\
\text { Rate }(A C / h r)\end{array}$} & \multicolumn{3}{|c|}{ Contaminant Concentrations" } \\
\hline & & & $\begin{array}{c}\text { Co } \\
\left(\mathrm{mg} / \mathrm{m}^{2}\right)\end{array}$ & $\begin{array}{l}\mathrm{NO}_{2} \\
\left(\mu \mathrm{g} / \mathrm{m}^{2}\right)\end{array}$ & $\begin{array}{l}\mathrm{HCHO}^{\circ} \\
\left(\mu \mathrm{g} / \mathrm{m}^{*}\right)\end{array}$ \\
\hline No stove-vent or hood & & 0.25 & 48 & 2500 & 460 \\
\hline Hood vent (with no fan) above stove & & 1.0 & 25 & 1500 & 280 \\
\hline Hood vent with fan at high speed & $240(140 \mathrm{ctm})$ & 7.0 & 4 & 200 & 40 \\
\hline \multicolumn{6}{|c|}{ Typical Outdoor } \\
\hline - & Concentratic & ions During Test & 1.5 & 50 & 5 \\
\hline \multicolumn{6}{|c|}{ 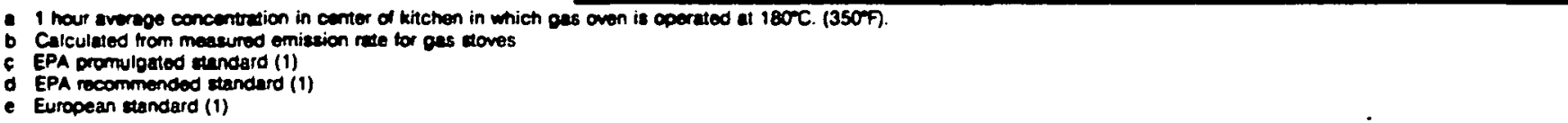 } \\
\hline
\end{tabular}

\section{TABLE 4}

Indvorlouldoor formaldehyde and aliphatic aldehyde concentrations measured at an emergy-fficient residence. August 1979.

\begin{tabular}{|c|c|c|c|c|}
\hline Condition & $\begin{array}{l}\text { Number of } \\
\text { Measurements }\end{array}$ & $\begin{array}{l}\text { Sampling } \\
\text { Time }\end{array}$ & $\begin{array}{c}\text { Formaldehyde } \\
\left(\mu g / m^{2}\right)^{2}\end{array}$ & $\begin{array}{c}\text { Niphatic } \\
\text { Aldehydes }\left(\boldsymbol{\mu g} / \mathrm{m}^{\prime}\right)^{\circ}\end{array}$ \\
\hline $\begin{array}{l}\text { Unoccupied. } \\
\text { without fumiture }\end{array}$ & 3 & 12 & $B O \pm 9 \%$ & $90 \pm 16 \%$ \\
\hline $\begin{array}{l}\text { Unoccupied, } \\
\text { with fumiture }\end{array}$ & 3 & 24 & $223 \pm 7 \%$ & $294 \pm 4 \%$ \\
\hline $\begin{array}{l}\text { Occupied, } \\
\text { daye }\end{array}$ & 9 & 12 & $261 \pm 10 \%$ & $277 \pm 15 \%$ \\
\hline $\begin{array}{l}\text { Occupied. } \\
\text { nightd }\end{array}$ & 9 & 12 & $140 \pm 31 \%$ & $178 \pm 29 \%$ \\
\hline
\end{tabular}

- Dedermined using pararocanilino method $\left(120 \mu \mathrm{g} / \mathrm{m}^{2}-100 \mathrm{ppb}\right)$. All outcide conoentrationt $<10 \mu g / m$ ).

b Dotermined using MBTH methoo, expressed as equivalents of tormaldehyde. All outside concentrations $\mathrm{r} .20 \mathrm{Mg} / \mathrm{m}^{2}$

c Air exchange rete $=0.4$ ACmi.

- Windows open par of time: air exchange rate signiticintly oreater than $0.4 \mathrm{ACMr}$ and variable. 
- Concentrations of sulfur dioxide, ozone sulphates, nitrates and lead are often lower indoors than outdoors; and

- On the average, the observed indoor air pollution concentrations were not high, but there were persistant moderate, sometimes elevated, levels in some of the monitored buildings.

The study supports the contention that various indoor air pollutants in résidences with gas appliances are aggravated by measures taken to reduce air infiltration rates. Nevertheless, indoor air quality was not drastically affected for air infiltration rates between 0.4 and 0.6 air changes per hour. 
The quality of indoor air is determined by the pollutants generated indoors from combustion, building contents or materials, human activities and those pollutants' secondary conversion products. The indoor environment is actually shielded from outdoor pollutant infiltration by reduced infiltration.

Employment of alternative energy practices could increase levels of indoor generated pollutants due to reduced ventilation, different quantities and ratios of pollutant-emanating building materials or different human activities.

While there appears to be an ample number of control strategies and methods, little is known concerning the proper application of the control measures. Much more research is required to identify the potentially hazardous pollutants and their exposure levels (i.e., concentrations and duration) which could potentially cause health risks in the alternative energy systems. 
1. Hollowe11, C.D., Berk, J.V., and Tarynor, G.W. "Indoor Air Quality Measurements in Energy Efficient Buildings," presented at the $71 \mathrm{st}$ Air Pollution Control Association Meeting, Houston, Texas, 1978.

2. Hollowell, C.D., Berk, F.V., Lin, C.I., and Turiel, I, "Indoor Air Quality in Energy Efficient Buildings," presented at the Second International CIB Symposium on ENergy Conservation in the Built Environment, Copenhagen, Denmark, 1979.

3. Budnitz, R.J., Berk, J.V., Hollowell, C.D., Nazaroff, W.W., Nero, A.V., and Rosenfield, A.H., "Human Disease from Radon Exposures: Impact of Energy Conservation in Buildings," Energy and Buildings, Vol. 2, 1978, Pp. 209-215.

4. Gage, S.J. and Rausa, G.J., "Overview of the Health Effects of Alternative Energy Sources," presented at the 71 st Annual Meeting of the Air Pollution Control Association, Houston, Texas, 1978, Paper No. 78-23.1.

5. Johnson, J.E. and Olson, M.O., "Measurement of 222-Rn Build-Up in Solar Heated Buildings in Calculation of Radiation Doses" U.S. Department of Energy Final Report c00-4546-2, 1978.

6. Scott, L.A., "Health Risks of Indoor Air Pollution," Unpublished Report for Solar Energy Research Institute, 1980. 